\title{
Democratic Principal (Kula Babong) Leadership Model: Examining the Role of Du'a Moan Watu Pitu in Sikka Krowe Community
}

\section{Model Kepemimpinan Kepala Sekolah Demokratis (Kula Babong): Mengkaji Peran Dua Moan Watu Pitu (Lembaga Pemangku Adat) Masyarakat Sikka Krowe}

\author{
Gisela Nuwa*, Rikardus Nasa \\ Institut Keguruan Dan Ilmu Pendidikan Muhammadiyah Maumere, Indonesia
}

Preserving culture is an important aspect of the life of indigenous peoples because it is identical to a lifestyle that is still guided by local customs. The process of cultural preservation in indigenous peoples cannot be separated from the important role of the community as an academic locus and Du'a Mo'an Watu Pitu as the responsible one.

OPEN ACCESS

ISSN 25482254 (online) ISSN 20893833 (print)

Edited by

Muhlasin Amrullah

Reviewedby:

Suciati Purwo

${ }^{*}$ Correspondence:

Gisela Nuwa

gustavnuwa123@gmaill.com

Received: 24 September 2021

Accepted: 18 November 2021

Published: 28 November 2021

Citation:

Nuwa G, NasaR, (2021)

Democratic Principal (Kula Babong) Leadership Model:

Examining the Role of Du'a Moan Watu Pitu in Sikka Krowe

Community.

Pedagogia: Jurnal Pendidikan. 11:1. doi: 10.21070/pedagogia.v11i1.1384 Based on this reality, this study aims to determine the leadership model of a democratic school principal based on local wisdom and examine the role of du'a moan watu pitu in maintaining the Kula babong culture (democracy) in the Sikka Krowe community. The research method used in this research is descriptive qualitative with an ethnographic approach. The subjects in this study were 4 principals of private and public schools, four Sikka krowe traditional leaders who inhabit each region, and culturalists in the Krowe Ethnic community, Sikka krowe Regency, East Nusa Tenggara. Data collection techniques used are observation, interviews and documentation. The results showed that the school principal's leadership model was based on the values of Sikka Krowe's local wisdom: the value of honesty, the value of courage, the value of kula babong, and charisma. Du'a Mo'an Watu Pitu's role in preserving the Kula Babong culture (democracy) is to maintain the integrity of traditional institutions, perform traditional rituals, resolve social conflicts and uphold justice.

Keywords: Principal Leadership, Democracy, Du'a Moan Watu Pitu

Melestarikan budaya menjadi aspek penting dalam kehidupan masyarakat adat karena identik dengan gaya hidup yang masih berpedoman pada adat istiadat setempat. Proses pelestarian budaya pada masyarakat adat tidak terlepas dari peran penting masyarakat sebagai lokus akademik dan Du'a Mo'an Watu Pitu sebagai yang 
bertanggung jawab. Atas dasar realitas inilah penelitian ini bertujuan untuk mengetahui model kepemimpinan kepala sekolah demokratis berbasis kearifan lokal dan mengkaji peran du'a moan watu pitu dalam menjaga budaya Kula babong (demokrasi) pada masyarakat Sikka Krowe. Metode penelitian yang digunakan dalam adalah deskriptif kualitatif dengan pendekatan etnografi. Subjek dalam penelitian ini adalah 4 kepala sekolah swasta dan negeri, 4 tokoh adat Sikka krowe yang mendiami masing-masing wilayah, dan budayawan pada masyarakat Etnis Krowe Kabupaten Sikka Nusa Tenggara Timur. Teknik pengumpulan data yang digunakan adalah observasi, wawancara dan dokumentasi. Hasil penelitian menunjukkan, model kepemimpinan kepla sekolah berbasis nilai kearifan lokal Sikka Krowe: nilai kejujuran, nilai keberanian, nilai kula babong, dan berkharisma. Peran Du'a Mo'an Watu Pitu dalam melestarikan budaya Kula Babong (demokrasi) yaitu menjaga integritas Lembaga Adat, Melakukan Ritual Adat, Menyelesaikan konflik sosial dan menegakan keadilan.

Kata Kunci: Kepemimpinan Kepala Sekolah, Demokrasi, Dua Moan Watu Pitu 


\section{PENDAHULUAN}

Masalah kepemimpinan sudah banyak diteliti oleh berbagai pihak dengan aneka sudut pandang dan hasil beragam terkait model dan gaya kepemimpinan kepala sekolah berbasis kearifan lokal. Iqbal (2019) dalam penelitiannya menjelaskan kepemimpinan nggusu waru mampu menerapkan program dan kebijakan strategis yang telah dimasukan dalam Rencana Strategis (Renstra) jangka panjang, menengah dan pendek dengan menerapkan 7 hari. Hari Senin: terpelajar dan berilmu (dou mo deiro pa ja ilmu), Hari Selasa: bertaqwa pada Tuhan yang Maha Esa (Dou ma Dahu din dai ru ma). Hari Rabu: orang yang berkelakuan baik (Dou ma toho ra rawi), Hari Kamis: menjaga nasab serta nama baik keluarga (dou ma ta hon tan da ba dou lodo main a), Hari Jumat: Karyasertaberbagi dan kejujuran dalam berkata dan berbuat, hari Sabtu: membela yang benar dan takut membela yang salah. Penelitian ini pada dasarnya mengupas eksistensi budaya lokal sebagai bentuk pengintegrasian dengan kepemimpinan kepala sekolah.

Selanjutnya Berlian (2012) menjelaskan terdapat korelasi antara faktor budaya lokal dengan pembangunan bidang pendidikan dibeberapa etnik di Indonesia. Terutama dalam hal ini keanekaragaman model kepemimpinan lokal sebagai roh pergerakan komunitas masyarakat lokal. Atas dasar ini Harsoyo (2017) dalam penelitianya memaparkan tiga urutan popularitas nilai-nilai kepemimpinan menurut kepala sekolah adalah asta brata, sitem among, dan sastra gendhing. Kepemimpinan kepala sekolah mempunyai dampak pada organisasi sekolah, seperti misalnya dampak pada struktur, rencana, dan tujuan sekolah pada akhirnya membawa dampak langsung pada kondisi kelas, seperti prosedur, kebijakan, dan pengalaman dikelas Leithwood \& Jantzi (1999) dan juga budaya kolaboratif sekolah. Demir (2008) Dengan demikian pernyataan di atas mengungkapkan kepala sekolah pada tataran tertentu sudah baik ditinjau dari aspek kompetensi sosial dan aspek kepribadian, namun masih cukup pada aspek kompetensi manajerial, kompetensi kewirausahaan, dan spek supervisi.

Bicara tentang kepemimpinan kepala sekolah secara positif, tergambar dalam kepuasan atas kualitas kehidupan kerja Lestari (2016); kinerja guru Ahmad (2017); motivasi kerja guru; komitmen afektif guru terhadap organisasi Zein (2018); komitmen organisasional dan perilaku ekstra peran Jati (2013). Meskipun demikian, dalam hal tertentu kepala sekolah belum memahami nilai-nilai kepemimpinan berdasarkan kearifan lokal. Padahal idealnya dalam organisasi kepemimpinan, seorang pemimpin harus mampu memahami karakter yang dipimpinnya bukan hanya kerangka konseptual, tetapi juga harus dipahami dari aspek budaya. Budaya yang melekat dalam diri seorang yang dipimpinnya merupakan faktor bawaan hanya bisa dipahami oleh seorang pemimpin dalam koridor kearifan lokal di daerahnya. Kebaruan dari penelitian ini terletak pada proses pengintegrasian nilai-nilai budaya dan kearifan lokal etnik Sikka Krowe dalam pola kepemimpinan kepala sekolah di Kabupaten Sikka. Konsep ini dapat dikaitkan dengan adanya konsesus integrasi nasional menuju pengabdian kepada Civil Society sebagaimana pandangan Cliford Geertz dalam Suswandari (2019). Penelitian ini mengarah pada upaya memetakan model kepemimpinan berbasis kearifan lokal yang lahir dari budaya lokal Sikka sesuai dengan konteks dan karakter setempat, dan selanjutnya menjadi sumbangsih bagi kepala sekolah seluruh Indonesia.

Kebudayaan merupakan pandangan hidup dari sekelompok orang dalam bentuk perilaku, kepercayaan, nilai, dan simbolsimbol yang mereka terima tanpa sadar yang semuanya diwariskan melalui proses komunikasi dari satu generasi kegenerasi berikutnya. Brata (2016) Budaya juga memiliki beberapa nilai-nilai yang perlu diperhatikan keberadaannya Effendy (2017). menjelaskan bahwa nilai budaya sangat penting karena dapat digunakan sebagai seperangkat keyakinan yang mempengaruhi sikap dan perilaku seseorang atau kelompok dalam kehidupan di masyarakat. Dalam konteks kepemimpinan kepala sekolah juga demikian mestinya harus mampu menempatkan keyakinan yang lahir dari budaya sebagai roh dalam hal memimpin, terutama nilai kulababong (demokrasi) itu sendiri.

Manusia saat ini sudah dihadapi oleh realitas yang kian maju, terbukti dari budaya-budaya modern yang muncul telah mengisi kehidupan manusia, terutama pada kemajuan teknologi industri dan informasi. Berbagai perubahan yang terjadi di Indonesia tidak hanya menyangkut tatanan kehidupan sosial ekonomi, tetapi juga politik, bahasa, dan kebudayaan. Ditengah kemajuan zaman seperti ini tentu kita tidak boleh melupakan akar budaya yang telah ada karena budaya-budaya itu mengandung nilai-nilai yang sangat luhur yang perlu dilestarikan. Sartini (2009) Maka terhadap pernyataan ini eksistensi budaya sebagai warisan sejarah bagi hidup manusia mesti diperlakukan layaknya seperti harta yang berharga untuk selalu dipelihara dan dijaga. Salah satu tempat yang paling baik untuk menjaga eksistensi budaya agar tetap awet adalah melaui dunia pendidikan. Suswandari \& Armiyati (2019) mengatakan dunia pendidikan merupakan jalur efektif dalam menumbuhsuburkan nilai-nilai multikulturalisme budaya untuk mempertahankan dan memperkuat Indonesia sebagai Negara kesatuan. Salah satunya melalui penerapan dalam kepemimpinan kepala sekolah berbasis kearifan lokal.

Kearifan lokal yang mengandung nilai-nilai, karakter dan filosofi yang hidup di daerah merupakan sumber etika, bagian dari kekayaan kultural bangsa yang harus dijaga, dipelihara dan dilestarikan sebagai dasar pegangan hidup dalam bermasyarakat. Eksistensi nilai-nilai budaya dan karakter nasional tidak akan berarti banyak tanpa ditopang oleh eksistensi nilai dan budaya yang ada di daerah, keduanya saling melengkapi dan menjadi isu strategis yang sama pentingnya, jika kita berasumsi nasionalisme perlu dipelihara oleh semua warga negara untuk keberlangsungan martabat bangsa, maka di daerah selain nasionalisme, juga perlu dikembangkan nilai-nilai budaya lokal dianggap bisa memberi dampak positif terhadap kehidupan sosial budaya yang ada di masyarakat. Pitono (2013) Demikian juga dalam hubungannya dengan kepemimpinan kepala sekolah nilai-nilai kearifan lokal perlu diterapkan, terutama model demokratisasi yang dikembangkan oleh dua moan watu pitu (sebutan bagi lembaga pemangku adat) masyarakat lokal. Dalam konteks ini yang perlu diangkat yaitu semangat demokratisasi dari kepemimpinan lokal yang rii dan bukan dari konsep demokrasi secara universal. Seperti yang diuraikan oleh Iqbal (2019) terkait gaya kepemimpinan kepala sekolah berbasis kearifan lokal manggusu waru di Bima. Kajian ini secara khusus 
mengupas gaya kepemimpinan yang lahir dari kebajikkan lokal setempat. Hal ini juga tentu memiliki perbedaan dengan gaya kepemimpinan dari dua moan watu pitu Sikka Krowe di Kabupaten Sikka.

Pada prinsipnya pola kepemimpinan diperlukan usahausaha menemukan nilai-nilai budaya yang beraneka ragam tersebut dengan memahami perbedaan dan persamaan di antara mereka dalam semangat kebhinekaan. Cara pemimpin dalam ragam budaya memahami organanisasi antara lain mengenai bahasa dan budaya, dengan membentuk tim kerja yang serasi dan padu diperlukan informasi tentang sejarah dasar daerah tersebut dengan ciri-ciri kebudayaan dan mempelajari bahasa daerah dalam membangun tim yang kuat dalam organisasi. Hidayat (2008).

Permendikbud RI No. 10 Tahun 2014 Tentang Pedoman Pelestarian Tradisi menjadi dasar bagi kepala sekolah dalam menerapkan kepemimpinan yang berbasis pada nilai-nilai kearifan lokal kula babong. Kabupaten Sikka sebagai salah satu daerah yang berada di Indonesia memiliki keunikan budaya, karena di dalamnya terdapat lima etnis berbeda yaitu Sikka Krowe, Lio, Palu'e, Tanah Ai'i, dan Pendatang (Gisela Nuwa, 2020). Fokus penelitian ini mengangkat etnis Sikka Krowe sebagai acuan penerapan kepemimpinan kepala sekolah, dalam hubungan dengan nilai kula babong (demokrasi). Posisi etnis Sikka Krowe dalam hal ini sangat mempengaruhi seluruh karakteristik kepemimpinan kepala sekolah di kabupaten Sikka. Peneliti akan mengkaji secara mendalam tentang nilai-nilai kearifan lokal etnik Sikka Krowe kula babong (demokrasi) sebagai Value Based dalam pengembangan kepemimpinan kepala sekolah dalam rangka penguatan model kepemimpinan di era perubahan global saat ini. Maka dengan demikian tujuan dari penelitian ini adalah menggali model kepemimpinan kepala sekolah berbasis nilai kearifan lokal kula babong (demokrasi) etnik Sikka Krowe di Kabupaten Sikka..

\section{METODE}

Metode yang digunakan dalam penelitian ini adalah kualitatif dengan jenis etnografi. Proses penelitian akan diulas berikut ini:. Alur penelitian selama satu tahun dengan langkah sebagaimana berikut di bawah ini.

\section{[Figure 1 about here.]}

Lokasi Penelitian: Penelitian dilaksanakan di wilayah Kabupaten Sikka Nusa Tenggara Timur dengan fokus Etnik Sikka Krowe dan SMP dan SMA Negeri dan Swasta yang ada di Kawasan tersebut. Penelitian ini bermula dari mencari tahu Model kepemimpinan kepala sekolah yang terdapat di kabupaten Sikka. Stelah itu menggali model kepemimpinan kearifan lokal etnik Sikka Krowe dan selanjutnya melakukan analisis untuk memperoleh model kepeminpinan kepala sekolah yang ideal. Tentu semua proses ini untuk memperoleh konsep yang jelas sebagai bentuk rekomendasi bagi pemerintah setempat dan bagi para kepala sekolah sekabupaten Sikka untuk diterapkan. Kerangka konsep penelitian selama satu tahun akan terlihat pada bagan berikut.

[Figure 2 about here.]
Informan dalam penelitian ini adalah tokoh masyarakat, tokoh adat, dan kepala sekolah serta guru Negeri dan Swasta di Kabupaten Sikka.Metode pengumpulan data yang dilakukan dalam penelitian ini adalah, 1) data profil kepemimpinan kepala sekolah dengan menggunakan observasi dan wawancara; 2) Data Budaya serta nilai kearifan lokal kepemimpinan etnik Sikka Krowe, diperoleh dengan melakukan pengamatan terlibat peneliti dengan penduduk setempat serta wawancara mendalam dan studi dokumentasi. Data penelitian kualitatif yang berkaitan dengan budaya dan nilai-nilai kearifan lokal, dianalisis dengan menggunakan analisis etnografi sebagaimana dikembangkan oleh Sprandley (1999), yang disebut dengan analisis 12 langkah alur maju bertahap, sebagaimana bagan berikut dibawah ini.

[Figure 3 about here.]

Teknik triangulasi data, dilakukan dengan: 1). perpanjangan pengamatan, 2). meningkatkan ketekunan dalam hal ini peneliti melakukan pengamatan secara lebih cermat dan berkesinambungan, sehingga kepastian data dan urutan peristiwa akan dapat direkam secara pasti dan sistematis.

\section{HASIL DAN PEMBAHASAN}

\section{Kepemimpinan Kepala Sekolah Berbasis Nilai Kearifan Lokal Etnik Sikka Krowe Di Kabupaten Sikka}

Ada beberapa nilai kearifan lokal etnik Sikka krowe di kabupaten Sikka dianggap relevan oleh peneliti untuk diterapkan dalam kepemimpinan kepala sekolah, yaitu Nilai kejujuran (tutur harang nora gu"a dena tepo naruk dadi) Ita dadi ata mo'an tutur naha ewe wu'ut, harang naha ewe lalat tutur tena riwun ngasung glenga mole persaya lora ita. (kita jadi pemimpin harus berbicara sesuai dengan apa yang terjadi, agar disukai dan dipercaya oleh masyarakat). Nilai kejujuran merupakan sesuatu hal yang sangat fundamental untuk diterapkan dalam diri seorang pemimpin. Nilai kejujuran ini sebenarnya tidak perlu diajarkan, namun sudah ada dalam konteks kehidupan manusia bersama dengan kebajikan lokal. Fakta ini terlihat jelas dalan kearifan lokal Sikka Krowe yang memiliki korelasi dengan apa yang diungkapkan oleh Mustari (2011) jujur adalah suatu perilaku yang didasarkan pada upaya menjadikan dirinya sebagai orang yang selalu dapat dipercaya dalam perkataan, tindakan dan pekerjaan, baik terhadap dirinya maupun pihak lain.

Nilai kejujuran perlu diterapkan dalam kepemimpinan kepala sekolah, agar mampu membentuk citra dirinya untuk dapat dipercaya baik dalam perkataan maupun tindakan demi terwujudnya kemajuan sekolah dan keberhasilan peserta didik. Hal ini menurut Julaiha (2015) disebut dengan keterampilan manusiawi, dimana ada korelasi antara komunikasi dengan keterampilan jati diri yang sempurna. Dengan demikian jika nilai kejujuran ini dimiliki oleh kepala sekolah, maka akan menumbuhkan kepercayaan dari peserta didik, tenaga pendidik, dan masyarakat sekitar. Tentu hal yang terpenting yaitu melalui perbuatan dan perkata yang baik sesuai dengan tata nilai budaya lokal setempat, seorang kepala sekolah telah menunjukkan marwah dirinya sebagai seorang 
pemimpin.

Nilai keberanian : Ita dadi ata moa'an naha li'ar dira rang ngang (kita jadi pemimpin harus memiliki karakter yang tegas dan berwibawa). Soleha (2019) mengartikan keberanian sebagai suatu tindakan memperjuangkan sesuatu yang dianggap penting dan mampu menghadapi segala sesuatu yang dapat menghalanginya. Memperjuangkan kepentingan bersama dalam kepemimpinan masyarakat adat merupakan sesuatu hal yang perlu diterapkan dan dihidupi dalam diri seorang pemimpin. Dalam filosofi masyarakat Sikka Krowe disebut dengan liar dira rang ngang. Seorang pemimpin harus mampu menampilkan diri dengan tegas dan berwibawa. Liar dira rang ngang sangat pantas untuk diterapkan dalam kepemimpinan kepala sekolah. Hanya melalui semangat keberanian seorang pemimpin mampu untuk mencapai tujuan tentu. Untuk mencapai tujuan tertentu seorang pemimpin harus mengedepankan sikap tegas. Dengan demikian semangat keberanian dan ketegasan dapat menghantar yang dipimpinnya mencapai cita-cita atau tujuan bersama. Dalam hal ini yaitu memajukan sekolah, serta mencerdaskan peserta didik yang memiliki karakter yang baik. Pemimpin yang berani bukan pemimpin yang tidak memiliki rasa takut, melainkan seseorang yang mampu mengendalikan ketakutan dengan bertindak tegas dan mengambil keputusan yang rasional. Nilai Musyawarah Untuk Mufakat (kula babong). Istilah yang dipakai dalam Sikka Krowe yaitu Ita dadi ba'a ata mo'an naha tena lahi lekang weli naruk lalan, ita naha 'era 'lora-'lora, lopa plikut rimu ganu watu, sa' an rimu ganu tana, naruk gete naha dadi naruk kesik, naruk kesik naha dadi potat (kita jadi pemimpin harus mampu menyelesaikan masalah, kita harus berdiri di tengah-tengah, jangan tindih mereka seperti batu, timbun mereka seperti tanah, masalah besar harus menjadi kecil, dan masalah kecil harus dihilangkan).

Kamus Besar Bahasa Indonesia (2005) musyawarah merupakan pembahasan bersama dengan maksud mencapai keputusan atas penyelesaian masalah. Prinsip musyawarah atau "Kula Babong" adalah bagian dari demokrasi yang harus diterapkan oleh seorang pemimpin dalam menghadapi dan menyelesaikan masalah untuk mencapai sebuah persetujuan atau mufakat. Musyawarah atau "Kula Babong" merupakan salah satu dari nilai-nilai kearifan lokal budaya Sikka Krowe yang dipandang mampu untuk menyelesaikan setiap masalah yang dihadapi, sehingga jika nilai ini diterapkan di lingkungan masyarakat, maka akan sangan efektik untuk dapat menyelesaikan setiap masalah yang dihadapi di lingkungan sekolah. Dalam kepemimpinannya, kepala sekolah selalu menerapkan musyawarah dan kerjasama dengan staf guru di sekolah jika ada kendala yang dihadapi. Dengan musyawarah ditemukan cara untuk mempersatukan manusia satu dengan yang lainnya, dengan musyawarah pula manusia dapat bertukar pikiran dan pendapat demi tercapainya sebuah tujuan bersama, selain musyawarah, kerjasama tim juga merupakan suatu hal yang sangat penting dalam sebuah kepemimpinan. Kerjasama menjadi kebutuhan dalam mewujudkan keberhasilan kineja kerja dan prestasi kerja. Dengan kerjasama komunikasi akan berjalan baik dengan dilandasi kesadaran dan tanggung jawab setiap anggota.

Maka musyawarah dan kerjasama merupakan dua hal yang sangat penting dalam kepemimpinan seorang kepala sekolah guna menopang tugas dan tanggungjawabnya sebagai seorang pemimpin demi tercapainya keberhasilan sebuah lembaga pendidikan. Thoha (2012) kepemimpinan dalam hubungan dengan demokratis merupakan kemampuan dalam mengubah orang lain agar besedia bekerja untuk mencapai tujuan yang telah ditetapkan, segala kegiatan yang akan dilakukan ditetapkan bersama antara pimpinan dan bawahan.

Berkharisma : "Dadi ata moan naha donen modung mior" (menjadi seorang pemimpin harus memiliki karisma yang baik). Dalam konteks kepemimpinan Moan Teka Iku, kharismatik seorang pemimpin tergambar dengan jelas dalam semboyan yang digunakan (dalam bahasa Sikka disebut dengan Kahe) pada saat memimpin perang. Nuwa (2020). Maka dalam konteks tertentu kharisma diartikan sebagai suatu kekuatan luar biasa yang dimiliki oleh seseorang. Weber selalu menggunakan istilah kharisma dalam arti suatu kualitas luar biasa yang dimiliki oleh seseorang atau suatu benda, sehingga orang atau benda tersebut dipandang memiliki kekuatan yang unik dan magis. Muchtarom (2000).

Keteladanan dalam suatu kepimpinan sangatlah penting. Pemimpin yang teladan dapat memberikan contoh yang baik dalam segala bidang, seperti kedisiplinan, keteladanan dalam bersikap, dan lain-lain Sofian (2015). Keteladanan sendiri merupakan salah satu semboyan dalam dunia pendidikan yang terkandung dalam 3 semboyan bapak pendidikan Indonesia Ki Hadjar Dewantara. Lepas dari sosok Ki Hadjar Dewantara secara pribadi, tiga semboyan beliau yang mampu menjadi pilar penopang dalam suksesnya seorang guru dan juga seorang kepala sekolah sebagai pemimpin untuk menuntaskan pendidikan karakter di Indonesia, ketiga semboyan tersebut salah satunya adalah "Ing Ngarsa Sung Tuladha" yang mempunyai arti ketika berada di depan harus memberi teladan. Oleh karena itu kepemimpinan dalam dunia pendidikan harus mampu menjadi teladan untuk peserta didik dan juga para pendidik. Harsoyo (2019)

Jika kepala sekolah sebagai seorang pemimpin sadar bahwa keteladanan adalah upaya nyata dalam membentuk karakter anak bangsa, semua kita tentu akan terus mengedepankan keteladanan dalam segala perkataan dan perbuatan.

\section{Peran Du'a Mo'an Watu Pitu Dalam Melestarikan Budaya Kula Babong (demokrasi)}

\section{Menjaga Integritas Lembaga Adat (Du'a Mo'an Watu Pitu)}

Integritas dari segi teoritis yaitu integritas yang berasal dari kata "Integer" yang artinya utuh dan lengkap. Keutuhan itu dinyatakan dalam setiap keputusan dibuat berdasarkan prinsip etika dan moral yang menyeluruh. Ketika seseorang memiliki integritas diri yang tinggi, maka dapat diamati melalui tindakan, kata-kata, keputusan, dan hasil yang didapatkan. Menurut Henry (2007) ketika berbicara mengenai integritas, maka tidak akan terlepas dari upaya untuk menjadi orang yang utuh, yang tidak dapat dipisahkan, dan yang bekerja dengan baik dalam menjalankan fungsinya sesuai dengan kemampuannya. Menurut teori Great Man, dalam penelitian Syahril (2019) mengatakan bahwa seorang 
pemimpin besar terlahir sebagai pemimpin yang mencakup kharisma, intelegensi, kebijaksanaan, dan dapat menggunakan kekuasaan yang dimilikinya untuk membuat berbagai keputusan yang memberi dampak besar bagi sejarah manusia.

Sedangkan Integritas berdasarkan perspektif Du'a Mo'an Watu Pitu lebih terarah pada sifat nama lembaga adat itu sendiri (in se). Di mana integritas dalam perspektif masyarakat Etnis Krowe diartikan dengan du'a (perempuan atau ibu) sebagai sumber awal kehidupan manusia yang memiliki jiwa keibuan, kelemahlembutan dan kebijaksanana seperti Ina Nian Tanah Wawa (ungkapan yang diberikan kepada wujud tertinggi). Istilah Ina Nian Tanah Wawa ini dimaknai bahwa bumi layaknya seorang ibu atau perempuan yang memiliki jiwa penuh kasih, penopang, penjaga dan pemelihara keberlangsungan hidup bagi setiap makhluk di dalamnya. Ibu bumi (bumi pertiwi) mereka hormati karena manusia berasl dari tanah. Bumi juga menyediakan kebutuhan hidup mereka berupa air, tumbuh-tumbuhan, dan tempat hidup binatang-binatang Menurut konteks Lembaga Adat (mo'an watu pitu) seperti Ama Lero Wulan Reta atau dikenal dengan Bapak Langit. Bapak Langit mereka hormati karena mereka percaya bahwa langit merupakan tempat tinggal para leluhur yang sudah meninggal. Taniardi (2017). Menurut konteks Lembaga Adat Watu (Batu) bermakna sebagai seorang pemimpin harus mampu mengambil dan membuat keputusan yang bulat, kuat dan tegas. Ungkapan ini sejalan dengan Teori Great Man dalam penelitian Syahril (2019) yang mengatakan bahwa seorang pemimpin besar terlahir sebagai pemimpin yang memiliki berbagai ciri-ciri individu yang sangat berbeda dengan kebanyakan manusia lainnya. Ciri-ciri individu ini mencakup kharisma, intelegensi, keberanian, tegas, kuat, kecerdasan dan kebijaksanaan. Sedangkan pitu (tuju) menurut konteks Lembaga Adat yaitu dalam proses kula babong untuk menyelesaikan konflik sosial harus mengikuti alur dan prosedur yang sudah ditentukan dan angka tujuh (pitu) juga merupakan angka kesempurnaan yang artinya keputusan itu harus mutlak. Hal dapat kita lihat pada gambar di bawah ini

\section{[Figure 4 about here.]}

\section{Memimpin Ritual dan Adat Keagamaan}

Memimpin ritual adat dan keagamaan merupakan salah satu bidang tanggungjawab dari Lembaga Adat dengan melakukan serangkaian kegiatan yang dilaksanakan dengan tujuan simbolis sebagai hubungan dengan sang pencipta. Hal ini dapat dilihat dari frekuensi Lembaga Adat pada masyarakat Etnis Krowe melakukan tugas dan tanggung jawabnya dalam hal adat dan keagamaan yang diukur dari sudut pandang adat istiadat dan hukum adat yang berlaku. Sonia \& Sarwoprasodjo (2020) dalam penelitiannya mengatakan bahwa memimpin ritual adat dan keagamaan merupakan salah satu bidang tanggungjawab dari Lembaga Adat dengan melakukan serangkaian kegiatan yang dilaksanakan dengan tujuan simbolis sebagai hubungan dengan sang pencipta. Eksistensi Lembaga Adat bagi masyarakat Etnis Krowe dipercaya merupakan titisan roh dari para leluhur yang hidup dan mengikat dalam diri para dewan pemangku adat tersebut untuk menjaga alam dan lingkungan sekitar dari gangguan dan ancaman yang melanggar atau melakukan perbuatan pidana atau perdata bahkan juga yang melanggar nilai-nilai agama serta nilai-nilai tradisi setempat yang ditetapkankan secara adat oleh para pemangku adat (Du'a Mo'an Watu Pitu). Fernando (2020)

Miharja (2015) dalam penelitiannya menjelaskan peran lembaga adat dalam pelestarian budaya salah satunya yaitu memimpin ritual adat dan keagamaan. Hal ini dilakukan agar nilai-nilai budaya tetap dilestarikan dan terjaga secara turuntemurun. Selain itu juga lembaga adat dipandang sebagai manifestasi kehadiran Tuhan yang kelihatan dan sekaligus sebagai perantara antara masyarakat dengan kekuasaan yang tertinggi yaitu Tuhan.

Berdasarkan ulasan di atas, kapasitas seorang lembaga pemangku adat tidak saja mengurus hal-hal yang bersifat duniawi tetapi juga berurusan dengan keselamatan manusia dari berbagai ancaman. Urusan ini lebih nyatanya terlihat pada saat terjadi bencana melanda bangsa Indonesia (Virus Corona), maka di sinilah peran Lembaga Adat (Du'a Mo'an Watu Pitu) melakukan ritual tolak bala demi terhidar dari virus corona yang mematikan nyawa manusia. Hal ini dapat kita lihat pada gambar di bawah ini

\section{[Figure 5 about here.]}

\section{Menyelesaikan Konflik Sosial Dengan Damai dan Melembaga}

Manusia dalam kehidupan sosial, selalu tidak terlepas dari apa yang disebut sebagai konflik. Beragam konflik yang terjadi mulai dari dalam diri individu, antar individu, antar kelompok. Beragam konflik yang terjadi pula disebabkan oleh banyak faktor mulai dari masalah ekonomi, sosial, agama, ras dan budaya. Konflik yang terjadi pada masyarakat Etnis Krowe berdampak pada ketidakhamonisan dalam hidup bermasyarakat. Beragam konflik yang terjadi antara lain masalah batas tanah, perebutan harta warisan, konflik dalam kehidupan rumah tangga seperti (perselingkuhan dan perzinahan) selalu berujung pada kasus pembunuhan dan permusuhan yang berkepanjangan. Akibatnya pula masyarakat merasa terganggu dalam menjalankan aktivitasnya dalam memenuhi kebutuhan ekonomi karena masyarakat sebagian besar adalah petani. Arah penyelesaian konflik pada`masyarakat Etnis Krowe berujung pada ranah hukum atau lembaga pengadilan. Masyarakat Etnis Krowe merasa bahwa penyelesaian konflik sosial melalui ranah hukum akan menghasilkan ada pihak yang menang dan kalah sehingga pihak yang kalah akan meninggalkan rasa dendam. Pada masyarakat Etnis Krowe sering kita jumpai bahwa dalam hubungan interaktif antara manusia, tentu tidak luput dari perbedaan pendapat, kesalahpahaman, namun semuanya dapat diatasi secara baik, dengan berpedoman pada ajaran "Lopa Rusik Da'a Ilur Meti, Ela Sape Man Marak". Ajaran ini menuntun dan mengarahkan manusia untuk tidak berprinsip menang sendiri dan main hakim sendiri. Oleh karena itu sebagai salah satu alternatif masyarakat Etnis Krowe memilih Lembaga Adat sebagai pemimpin atau penengah dalam menyelesaikan konflik sosial. Pernyataan di atas sesuai dengan apa yang dikatakan oleh (Bachtiar, 2017) yang meneliti tentang Peranan Lembaga Adat Melayu Riau dalam Penyelesaian Konflik Tanah Ulayat menemukan bahwa 
Lembaga Adat sangat berperan aktif dalam menyelesaikan konflik, dengan ikut mendampingi masyarakat dan bahkan lembaga adat terjun langsung ke lokasi konflik. Hal tersebut dapat kita lihat pada gambar di bawah ini

\section{[Figure 6 about here.]}

\section{Menjamin Tegaknya Keadilan}

Keberadaan hukum ditentukan oleh perilaku, sifat, dan sikap yang berada dalam jiwa manusia sebagai kondrat berkehidupan dan bermasyarakat. Hukum dalam konteks Negara Indonesia yang menganut sistem demokrasi menjunjung nilai-nilai keadilan yang ada didalamnya yang secara prinsip keadilan bagi seluruh rakyat Indonesia. Negara yang demokratis mengedepankan konsep keadilan hukum dalam menciptkan Negara hukum yang memberikan rasa adil kepada setiap warga negaranya dengan peraturanperaturan yang teratur dalam penegakannya, sehingga menghasilkan hukum yang baik dan berkualitas demi mencapai tujuan keadilan serta kesejahteraan bagi rakyat Indoensia seutuhnya sebagai pemegang kekuasaan dan kedaulatan rakyat. Hayat (2015)

Dalam masyarakat demokratis keadilan merupakan citacita bersama, walaupun sebagian kecil masyarakat ada yang diperlakukan tidak adil. Keadilan masyarakat yang dibangun hendaklah keadilan yang tidak membeda-bedakan suku, ras, bangsa dan budaya. Keadilan yang dimaksud dalam demokratis adalah keadilan yang dimana masyarakat harus saling membantu satu sama lain dan hidup berdampingan Harefa (2017). Menurut kepercayaan masyarakat Etnis Krowe bahwa Untuk menjaga dan memupuk rasa persatuan, kesatuan, dan keadilan leluhur memegang teguh pada ajaran "witi e kikir , rema e epak" dan puli lau uri ita mogat babar reta waa ita mogat". Dalam terjemahan bebas ajaran ini mengandung arti "genggamlah beban di sesama telapak jinjinglah ringan dijari jemari dari buritan dukung mendorong pada haluan sama mendayung". Hikmah yang di ambil dari ajaran ini mengandung makna Hidup yaitu bahu membahu, atau jelasnya seperti maksud dari peribahasa berat sama di pikul, ringan sama di jinjing. Hal ini dapat kita lihat pada gambar di bawah ini.

\section{[Figure 7 about here.]}

Usman (2014) mengemukakan bahwa pemimpin adalah ilmu dan seni mempengaruhi orang atau kelompok untuk bertindak seperti yang diharapkan untuk mencapai tujuan secara efektif dan efisien. Dari definisi tersebut dapat dimengerti bahwa kepemimpinana ini erat kaitannya dengan organisasi yang mana didalamnya ada yang memberikan pengaruh yang dilakukan oleh seseorang dari anggota organisasi untuk membantu organisasi mencapai tujuannya.

Kepemimpinan merupakan kemampuan mempengaruhi orang lain untuk mencapai tujuan tertentu, sehingga dapat dikatakan kepemimpinan kepala sekolah berarti bahwa kemampuan seseorang yang dipercaya untuk memimpin sebuah lembaga sekolah dan mampu mempengaruhi bawahan atau mitra kerjanya untuk mencapai tujuaan bersama yaitu kemajuan lembaga pendidikan yang dipimpinnya. Syafrida (2015) Dalam kepemimpinannya kepala sekolah di kabupaten Sikka selalu berupaya menerapkan nilai-nilai kearifan lokal seperti musyawarah, kerja sama dan juga selalu memberi teladan yang baik bagi warga sekolah dan sebagai seorang pemimpin beliau harus memiliki karisma.

Implementasi nilai-nilai kearifan lokal dalam lingkungan sekolah tidak terlepas dari aspek kepemimpinan (Kepala Sekolah), sehingga pertanyaan mendasar yang perlu dijawab dalam hal ini adalah bagaimana implementasi nilai-nilai kearifan lokal dalam hal kepemimpinan? Kepemimpinan kepala sekolah berbasis kearifan lokal pada dasarnya mengoptimalisasi nilai-nilai budaya lokal yang relevan dengan konteks kepemimpinan itu sendiri. Hal ini Marhawati (2016) menjelaskan, kepala sekolah dalam menjalankan kepemimpinannya harus mencari cara atau strategi melalui nilai-nilai budaya masyarakat untuk mendukung pencapaian tujuan pendidikan di sekolah.

Fajarini (2014) berpendapat bahwa, kearifan lokal adalah nila-nilai yang berlaku dalam suatu masyarakat. Nilai-nilai tersebut diyakini kebenarannya dan menjadi pedoman dalam bertingkah laku dalam kehidupan sehari-hari. Berdasarkan pengertian tersebut, nilai adalah sesuatu penghargaan yang diberikan kepada benda, agar benda tersebut bermanfaat untuk memenuhi kebutuhan masyarakat. Nilai (Value) merupakan wujud dari aspek afektif (affectife domain) serta berada dalam diri seseorang dan secara utuh dan bulat merupakan suatu sistem, dimana bermacam-macam nilai seperti nilai keagamaan, sosial budaya, ekonomi, hukum, estetis, etik dan lain-lain, berpadu, serta saling mempengaruhi secara kuat sebagai satu kesatuan yang utuh.

Kearifan lokal terbentuk dari pola tingkah laku manusia. Oleh karena itu kearifan lokal dipandang sangat bernilai dan mempunyai manfaat tersendiri dalam kehidupan bermasyarakat. Sistem tersebut dikembangkan karena adanya kebutuhan untuk menghayati, mempertahankan, dan melangsungkan hidup sesuai dengan situasi kondisi dan kemampuan serta tata nilai yang diyahati oleh masyarakat. sehingga kearifan lokal harus terus menerus dijadikan sebagai pegangan hidup.

\section{KESIMPULAN}

Dewasa ini, salah satu krisis yang sering terjadi adalah kepemimpinan. Kepemimpinan yang sebenarnya sebagai model bagi suatu organisasi atau yang dipimpinya justru mengalami krisis gaya kepemimpinan. Hal yang paling jelas adalah kepemimpinan kepala sekolah yang sering menerapkan kepemimpinan bersifat sentralistik, tanpa ada inovasi dari dalam diri sang pemimpin. Akibatnya, lembaga yang dipimpinya tidak berjalan ideal. Dalam penelitian ini secara khusus mengulas model kepemimpinan berbasis nilai kearifan lokal yang diterapkan oleh lembaga adat du'a moan watu pitu terkait dengan demokrasi. Demokrasi Pancasila adalah demokrasi yang mengutamakan musyawarah untuk mufakat. Pada masyarakat Etnis Krowe nilai Demokrasi (musyawarah mufakat) dalam bingkai tradisi adat dikenal dengan istilah Kula Babong. Nilai demokrasi ini mesti menjadi semangat lokal bagi kepala sekolah dalam menjalankan tugasnya. Maka untuk lebih jelasnya uraian tentan model kepemimpinan terdapat pada poin hasil bagian pertama. Sedangkan peran dua 
moan watu pitu dibahas pada bagian kedua poin hasil dan pembahasan. Semua penjelasan ini merupakan bagian dari tujuan penelitian.

\section{UCAPAN TERIMA KASIH}

Terimakasih banyak kami ucapkan kepada Menteri Pendidikan terutama Dirjen Pendidikan tinggi yang telah memberikan kesempatan kepada kami melakukan riset tentang kepemimpinan model kepemimpinan kepala sekolah berbasis kearifan lokal Sikka Krowe. Selain itu juga ucapan terimakasih kami kepada lembaga perguruan tinggi IKIP Muhammadiyah sebagai rumah keberagaman atas dukungan dan motivasinya sampai dengan tuntas penelitian ini. Terimakasih juga kepada tim peneliti yang dengan caranya masing-masing bertanggung jawab menyelesaikan penelitian ini. Selain itu juga kami sampaikan ucapan terimakasih banyak kepada informan (tokon adat) dan kepala sekolah, serta guru-guru yang telah memberikan informasi yang berharga bagi kesempurnaan penelitian ini. Terimakasih juga kepada para pakar budaya yang telah memberikan masukan untuk kesempurnaan penelitian ini.

\section{REFERENCES}

Abdul Kholik Amirulloh Zein. (2018). Motivasi Kerja Guru dalam Pelaksanaan Tugas Mengajar di SMK Negeri Kota Bukittinggi. Bahana Manajemen Pendidikan; Jurnal Administrasi Pendidikan, 2(1), 210-219.

Ahmad, L. I. (2017). Konsep Penilaian Kinerja Guru Dan Faktor Yang Mempengaruhinya. Idaarah: Jurnal Manajemen Pendidikan, 1(1), 133-142. https://doi.org/10.24252/idaarah.v1i1.4133

Bachtiar, Mariyati. (2017). "Perananan Lembaga Adat Melayu Riau dalam Penyelesaian Konflik Tanah Ulayat di Provinsi Riau”. Dalam Jurnal Hukum Respublica. Vol. 16, No. 2 Hal. 298-312.

Beniharmoni Harefa, 2017, Peradilan Adat Nias dan Keadilan Restoratif, Jurnal Komunikasi Hukum, Vol. 3, No. 1, Hal. 40-49.

Brata, Ida Bagus, 2016, Kearifan Budaya Lokal Perekat Identitas Bangsa, Jurnal Bakti Saraswati, Vol.5, No. 1, hal. 9-16.

Demir. K. (2008). ransformational leadership and collective efficacy: the moderating roles of collaborative culture and teacher' self-efficacy. Egitim Arastirmalari-EurasianJournal of Educational Research, 33(5), 93-113.

Effendy, Chairil, 2017, Nilai-Nilai Budaya Dalam Teks Raja Ala, Jurnal Kajian Pembelajara dan Keilmuan, Vol. 1, No. 2, Hal. 1-12.

Fajarini, U. 2014. Peranan Kearifan Lokal Dalam Pendidikan Karakter. Universitas Islam Negeri ( UIN). Jakarta. Diakses pada tanggal 20 Oktober 2015:hal:123-125

Fernando, Abel (2020). Peran Du'a Mo'an Watu Pitu Sebagai Lembaga Pemangku Adat Dalam Proses Penyelesaian Perkara Tindak Pidana Melalui Sanksi Adat Desa Hewokloang Kabupaten Sikka. Skripsi. IKIP Muhammadiyah Maumere.

Harsoyo, Yohanes, 2019, PENGEMBANGAN DESAIN MODEL PELATIHAN KEPEMIMPINAN KEPALA SEKOLAH BERBASIS NILAI-NILAI KEARIFAN LOKAL

Hayat, H. (2015). "Keadilan Sebagai Prinsip Negara Hukum : Tinjauan Teoritis Dalam Konsep Demokrasi”. Padjajaran Jurnal : Ilmu Hukum. Vol 2, No.2 Hal. 388-408

Henry, Cloud. (2007). Integritas - Keberanian Memenuhi Tuntutan Kenyataan. Jakarta: Gramedia Pustaka Utama.

Hidayati. 2008. Kepemimpinan Dalam Keragamam Budaya, Diklat KepemimpinanTinggkat III Badan Pendidikan dan Latihan Propinsi NTB : Mataram.

Iqbal, Muhammad, 2019, Gaya Kepemimpinan Kepala Sekolah Berbasis Kearifan Lokal, Telaah Terhadap Karakteristik Kepemimpinan Bima Manggusu Waru Pada Madrasah Aliya Negeri 2 Kota Bima, Julnal Oryza,
Vol.8, No.2, Hal. 1-9

Jati, A. N. (2013). Kepemimpinan Transformasional, Kualitas Kehidupan Kerja, Dan Komitmen Organisasional Terhadap Perilaku Ekstra Peran: Studi Empiris Pada Para Guru Sekolah Menengah Pertama Rintisan Sekolah Berstandar Internasional Di Kabupaten Klaten. Universitas Muhammadiyah Surakarta.

Julaiha, Siti (2019), Konsep Kepemimpinan Kepala Sekolah, Jurnal Penelitian Pendidikan dan Pembelajaran, Vol. 6, No. 3, Hal. 51-62.

Leithwood\&Jantzi. (1999). Transformational School Leadership Effects: A Replication. Journal School Effectiveness and School Improvement, 10(4), 19.

Lestari, S. (2016). Pengaruh Kepemimpinan Kepala Sekolah Dan Kinerja Guru Terhadap Prestasi Siswa. Satya Widya, 32(2), 127. https://doi.org/10.24246/j.sw.2016.v32.i2.p127-132

Marhawati, 2016, Implementasi Kepemimpinan Kepala Sekolah Berbasis Nilainilai Budaya Huyula di Daerah Terpencil Gorontalo, Disertasi dan Tesis Program Pascasarjana UM, Malang: Universitas Muhammadiyah Malang.

Maspuri. (2013). Mantra menumbai pada masyarakat Melayu Rokan (Kajian Struktur teks, konteks sebagai bahan ajar di SMA Universitas Pendidikan Indonesia. Skripsi. Repositori Perpustakaan Unversitas Pendidikan Indonesia.

Miharja, D. (2015). "Keberagaman masyarakat adat Cikondang dalam menghadapi modernisasi". Journal of islamic and Social Studies. Volume 1 (Nomor 1): 1-7

Muchtarom, Zaini, 2000, Konsep Max Weber Tentang Kepemimpinan Karismatik, Jurnal Refleksi, Vol. 2, No.3, Hal. 14-23.

Mustari, Mohamad. (2011). Nilai Karakter. Yogyakarta: LaksBang PRESSindo.

Nur Berlian VA. (2012). Identifikasi faktor Faktor Budaya Yang memengaruhi Capaian Kinerja Pembangunan Pendidikan. Jurnal Penelitian Dan Pengembangan, 3(3), 1-9

Nuwa, Gisela, 2020, Menggali nilai-nilai kepahlawanan Mo'an Teka Iku ditinjau dari aspek Pembelajaran PKn, Jurnal Bhineka Tunggal Ika, Vol. 7, No. 2, Hal. 134-142. 2020, Lokal Genius Po'o, Maumere: IKIP Muhammadiyah

Pitono, 2013, Etika, Integritas dan Kearifan Lokal (Menciptakan Trust Masyarakat). https://ejurnaletika.files.wordpress.com/2016/08/je5112013-18351.pdf. Diunduh Tanggal 29/09/2019

Sartini. 2009. Menggali Nilai Kearifan Lokal Budaya Jawa Lewat Ungkapan (Bebasan, Saloka, dan Paribasa, Logat) : Jurnal Ilmu Bahasa dan Sastra Volume V No. 1 Tahun 2009. ISSN : 1858-083.

Sofian, Aulia, 2015, Pengaruh Keteladanan Kepemimpinan dan Penerapan Peraturan Terhadap Disiplin dan Dampaknya Pada Kinerja Pegawai Dinas Kesehatan Kabupaten Aceh Jaya, Jurnal Manajemen, Vol. 4, No.3, Hal. 101111.

Sonia, Tya, 2020, Peran Lembaga Adat dalam Pelestarian Budaya Masyarakat Adat Kampung Naga, Desa Neglasari, Kecamatan Salawu, Tasikmalaya, Jurnal Sains Komunikasi dan Pengembangan Masyarakatk, Vol. 4, no. 1, Hal. 113-124.

Soleha, Fadhiatus, 2019, Nilai Patriotisme Dalam Novel Kidung Dari Negeri Apung Karya Arsyad Salam dan Pemanfaatannya Sebagai Bahan Pembelajaran Sastra Di SMA, Pontianak: Universitas Tanjungpura.

Suswandari \& Sri Astuti. (2020). Kearifan Lokal Dalam Keragaman Etnik Di Kabupaten Sikka. Pustaka Belajar. Celeban Timur UH III/ 548 Yogyakarta

Syafrida, 2015, Kepemimpinan Kepala Sekolah, Jurnal Manajer Pendidikan, Vol.9, No5, Hal. 679-685.

Syahril, Sulthon. (2019). “Teori-teori Kepemimpinan”. Jurnal Ri'ayah, Vol. 04, No.02, Hal. 209-215

Taniardi, Putri Novita, 2017. "Relasi Sosial Budaya Ata Krowe dan Gunung Mapitara". Jurnal Berkala Arkeologi, Vol. 37, No. 1, Hal. 15-34.

Thoha, Miftah. 2012. Kepemimpinan dalam Manajemen. Jakarta : Rajawali Pers

Usman, Husaini. 2014. Manajemen Teori, Prakter, dan Riset Pendidikan. Bumi Aksara: Jakarta]

Conflict of InterestStatement:Theauthorsdeclarethat theresearchwasconducted in the absence of any commercial or financial relationships that could be construed as a potential conflict of interest.

Copyright@2021Siti Gisela Nuwa, Rikardus Nasa. Thisisanopen-accessarticledistributed under the terms of the Creative Commons Attribution License (CC BY). The use, distribution or reproduction in other forums is permitted, provided the original author(s) and the copyright owner(s) are credited and that the original publication in this journal is cited, in accordance with accepted academic practice. No use, distribution or reproduction is permitted which does not comply with these terms. 


\section{LIST OF FIGURE}

1 Alur Penelitian...

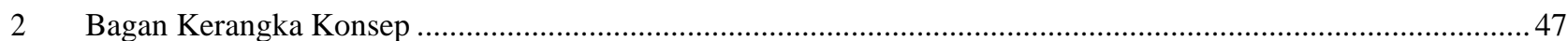

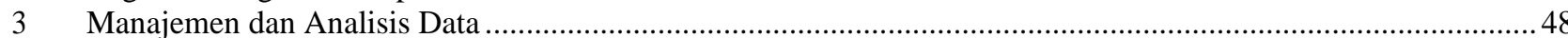

$4 \quad$ Lembaga Adat Du'a Mo'an Watu Pitu ......................................................................................................... 49

5 Ritual Tolak Bala di Etnis Krowe Kabupaten Sikka ............................................................................50

6 Proses Penyelesaian Kasus Perebutan Harta Warisan ................................................................................. 51

7 Gotong Royong Dalam Pembersihan Tempat Pembangunan Sekolah Baru ...............................................52 


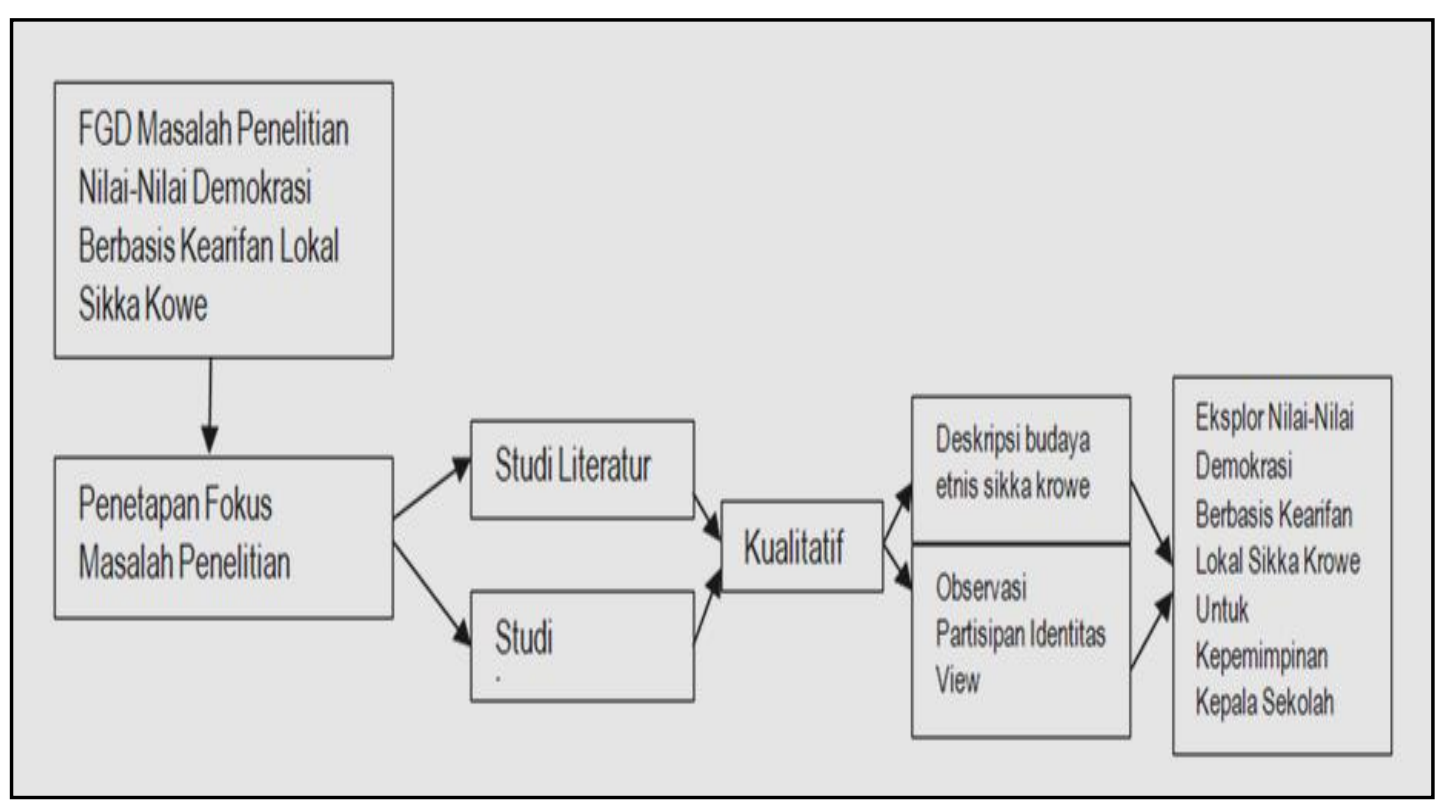




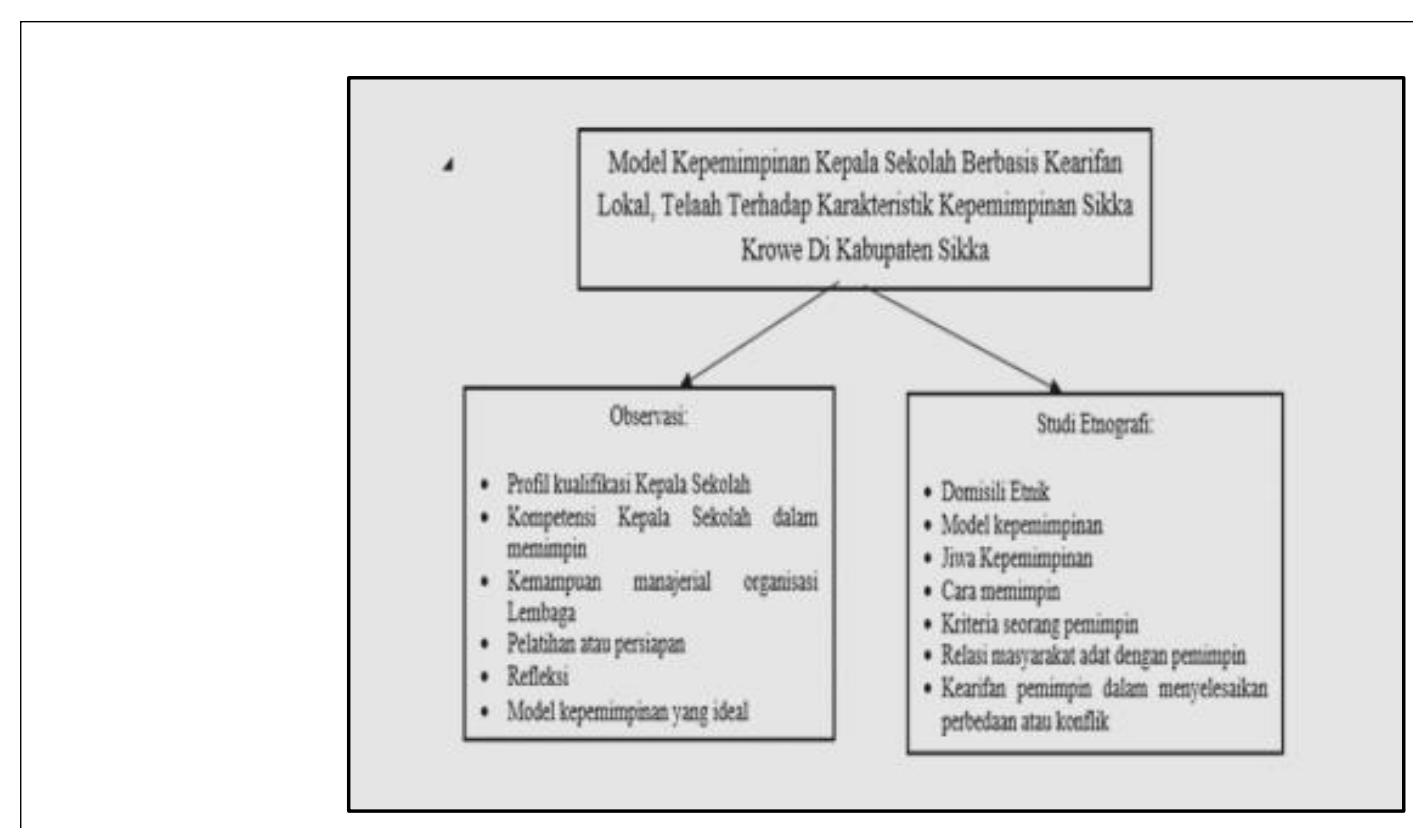

FIGURE 2 / Bagan Kerangka Konsep 


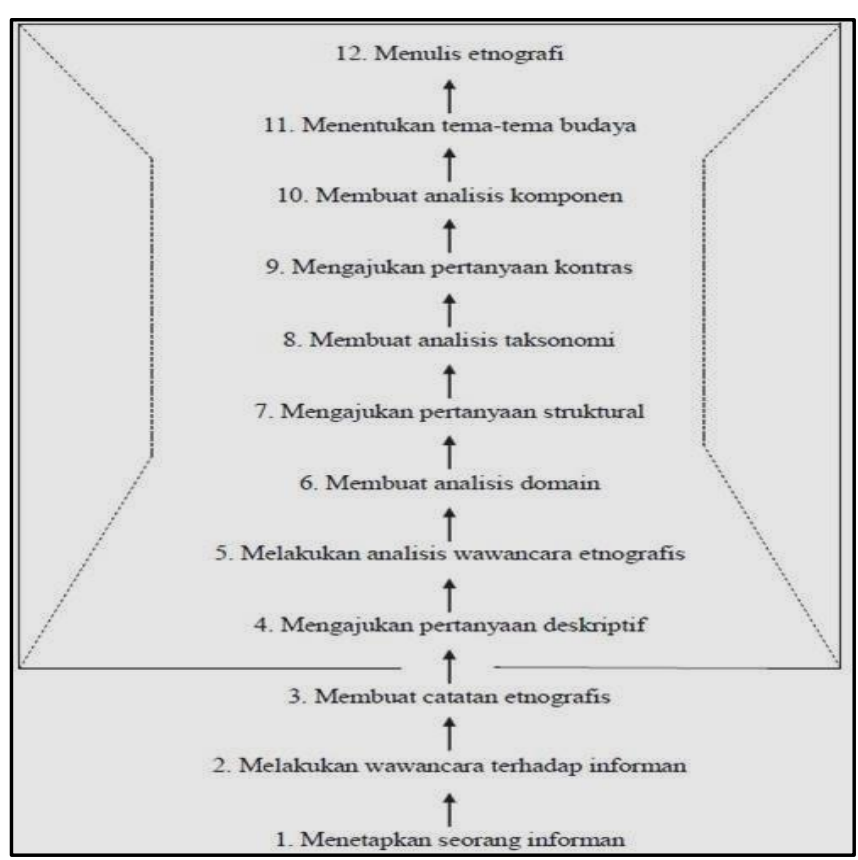

FIGURE 3 / Manajemen dan Analisis Data 


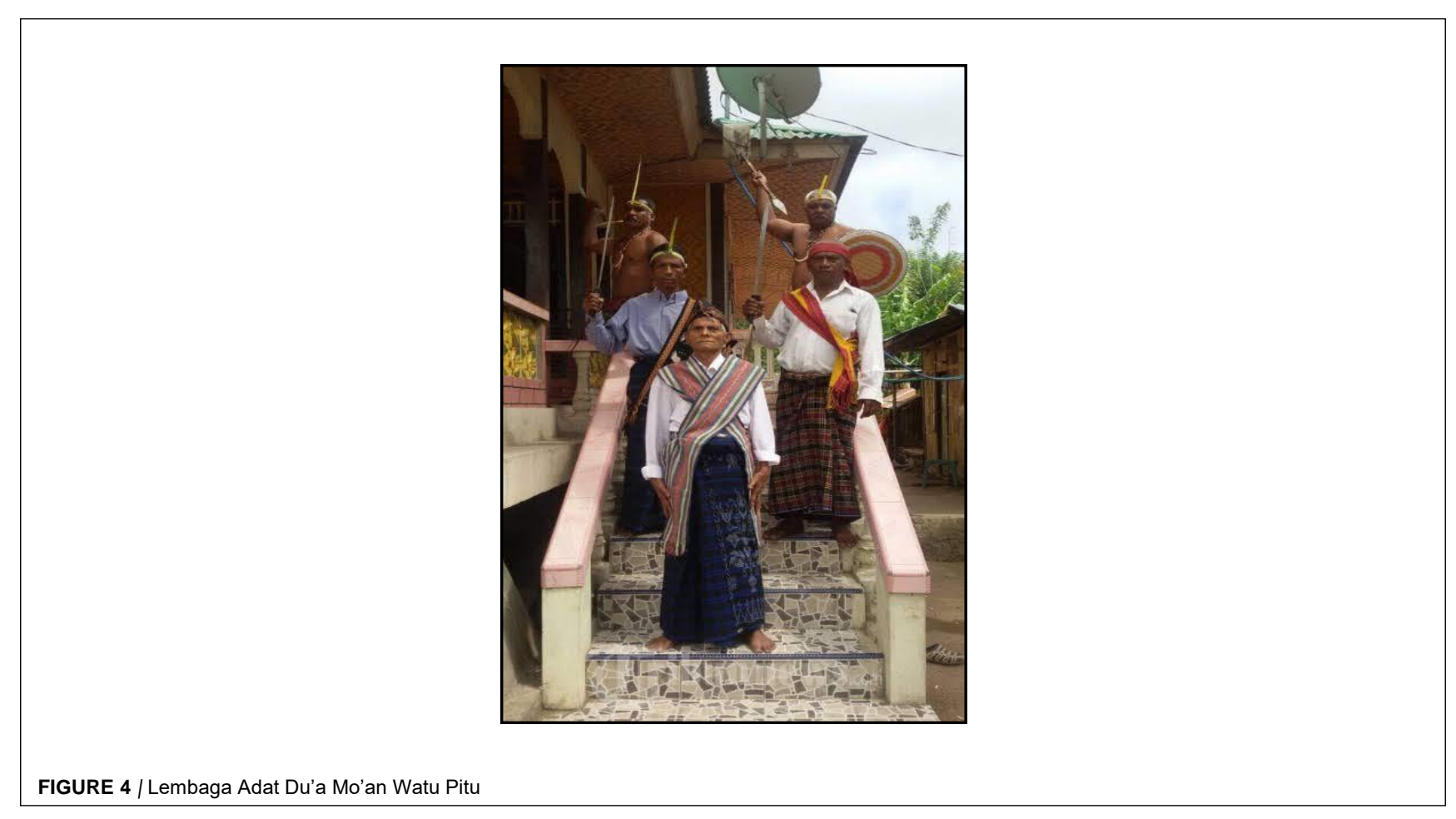




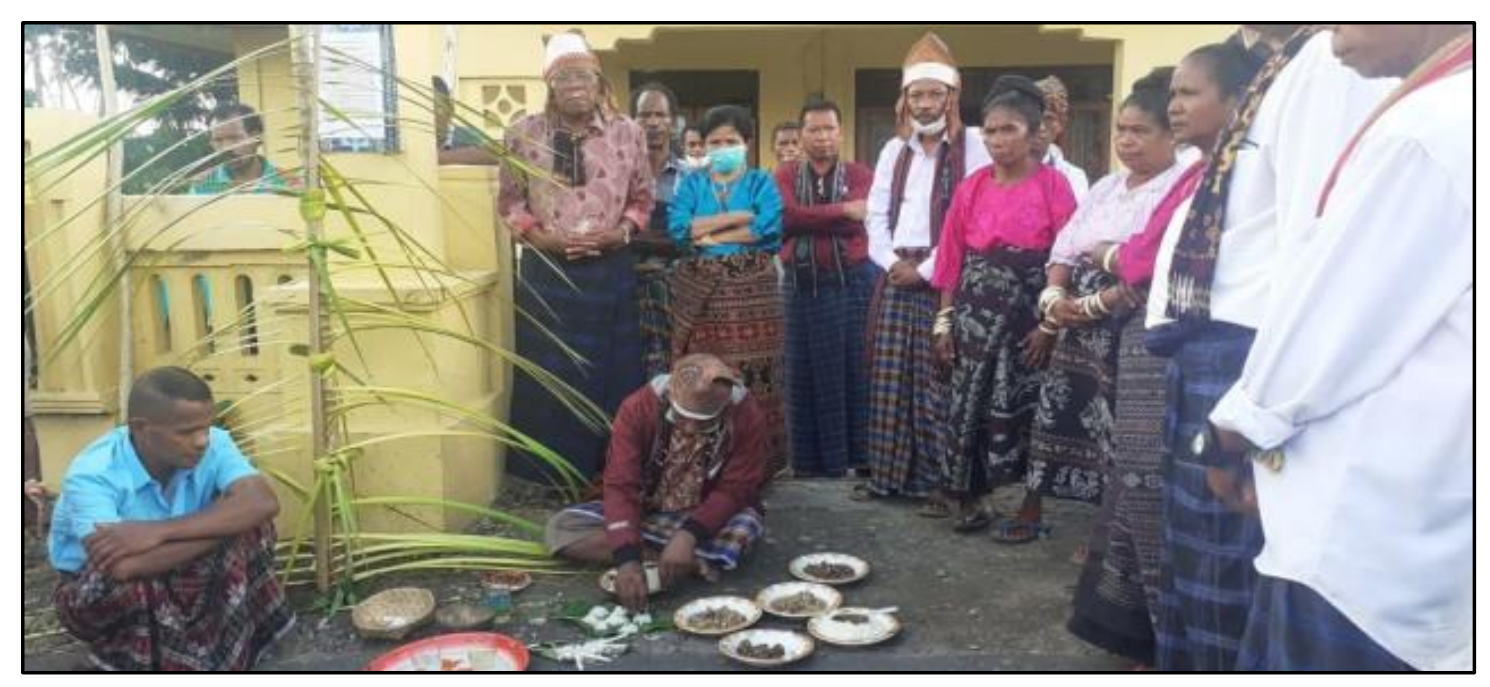

FIGURE 5 / Ritual Tolak Bala di Etnis Krowe Kabupaten Sikka 


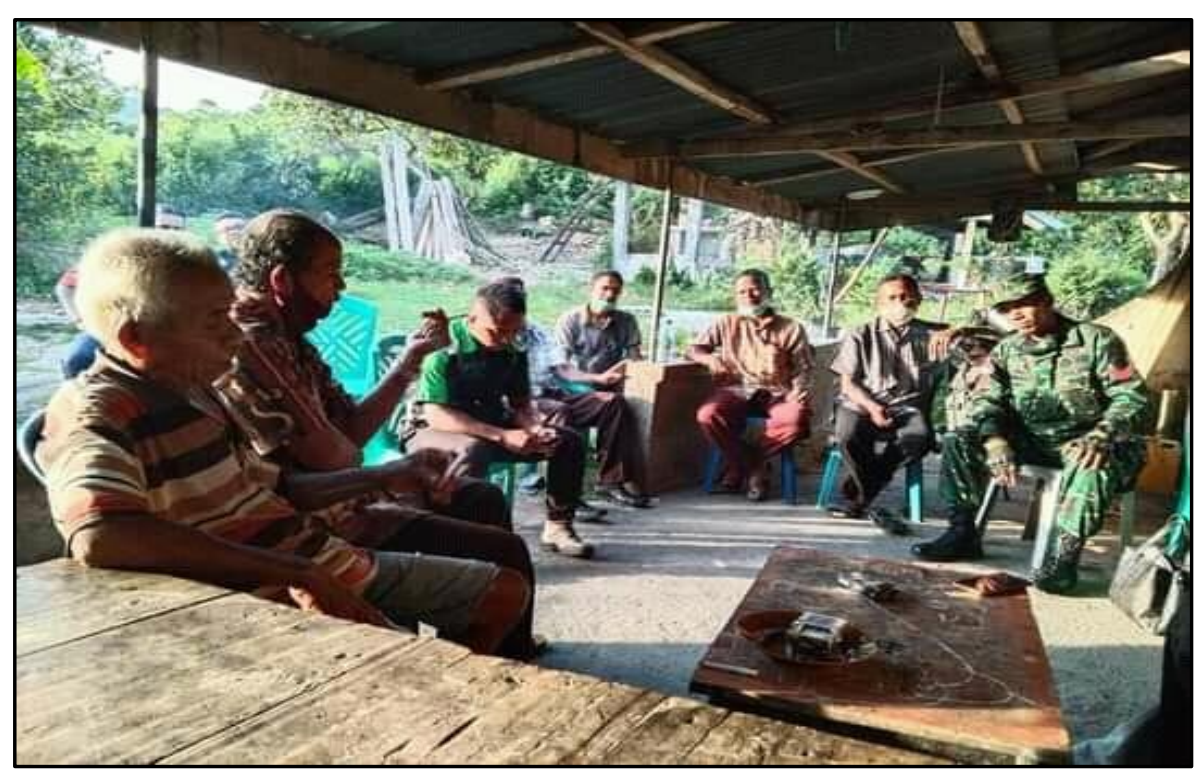

FIGURE 6 / Proses Penyelesaian Kasus Perebutan Harta Warisan 


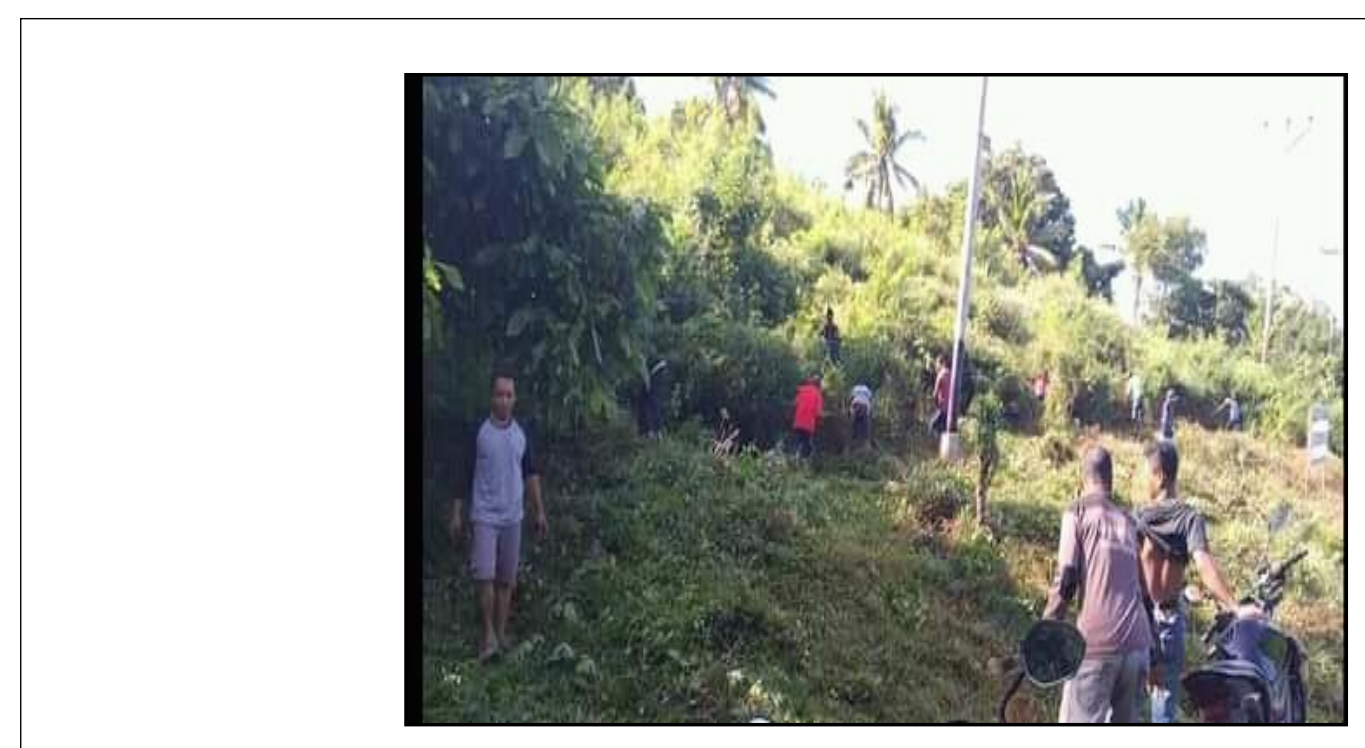

FIGURE 7 / Gotong Royong Dalam Pembersihan Tempat Pembangunan Sekolah Baru 